\title{
Effect of Chromium Plating on the Endurance Limit of Steels Used in Aircraft
}

\author{
By Hugh L. Logan
}

\begin{abstract}
Chromium plating reduced the endurance limits of both normalized and hardened (quenched and tempered) SAE X4130 steels; the reduction was larger for the hardened steel. The endurance limits for steel of a given hardness decreased with increased plating bath temperatures. Baking of the plated steel, at temperatures up to $350^{\circ} \mathrm{C}$, reduced the endurance limit; baking at $440^{\circ} \mathrm{C}$ increased the endurance limit of the plated steel. However (for hardened steel) baking did not restore the endurance limit to that of the unplated steel. Damaging effects of chromium on the endurance limits of plated steels are attributed to stresses in the chromium and/or steel, which are increased by low temperature baking but are relieved in part by baking at $400^{\circ}$ to $440^{\circ} \mathrm{C}$.
\end{abstract}

\section{Introduction}

During the period of 1930 to 1936 the Bureau of Aeronautics, Navy Department, submitted for examination a number of chromium-plated hollow-steel airplane propeller blades that had failed by fatigue in service. Preliminary fatigue tests in the laboratory confirmed conclusions, based on the examination of the propeller failures, that the endurance limit of the steel was materially reduced by chromium plating. In addition to the plating of propeller blades and other parts for protective purposes, manufacturers and maintenance shops were exploring the possibilities of reclaiming by chromium plating worn and undersize parts. These considerations prompted the Bureau of Aeronautics to support an extensive investigation conducted by the National Bureau of Standards on the effect of chromium plating on the endurance limits of steels used in aircraft.

Two steels designated SAE X4130 and 6130 were used in the investigation. However, most of the tests were made on X4130 steel, heat treated to a hardness of about Rockwell 40-C, with an ultimate tensile strength of approximately $180,000 \mathrm{lb} / \mathrm{in}^{2}$

The first phase of this study provided for the determination of the effects of chromium, as plated, on the endurance limit of the steels. The variables studied were: (1) plate thickness, (2) hardness of the steels plated, (3) current densities and temperatures of the plating baths, (4) surface grinding of the chromium after plating, and (5) interruptions of the plating process.

A second phase of the investigation was a systematic study of the effect of heating on the endurance limit of specimens of chromium-plated $\mathrm{X} 4130$ steel. If the decrease in the endurance limit of the plated steel is attributable to the large quantities of hydrogen evolved at the cathode during the process of chromium plating, then it appears that the endurance limit may be increased by the removal of hydrogen by heating. However, Swanger and France [1] ${ }^{1}$ found that heating the specimens for 5 hours at $350^{\circ} \mathrm{F}\left(182^{\circ} \mathrm{C}\right)$ reduced the endurance limit of the plated steel to about 70 percent of that of the plated but unheated material. Wiegand and Scheinost [2] also reported that heating of chromium plated steel at $250^{\circ} \mathrm{C}$ decreased its endurance limit. Other workers have spot checked the effect on the endurance limit of heating chromium-plated steel. However, no systematic study of the effect of heating had been made.

A theory has been developed to explain, at least in part, the effects of chromium plating on the endurance limit of the steels studied.

\footnotetext{
1 Figures in brackets indicate the literature references at the end of this paper.
} 
Publication of this material, including data circulated during wartime in reports [3] that at that time were restricted but have since been declassified, has been approved by the Bureau of Aeronautics, sponsor of the investigation.

\section{Materials}

The materials, from which the specimens for this investigation were machined, consisted of three lots of SAE X4130 rod and one lot of 6130 rod. The compositions of these steels, as determined by chemical and spectrochemical analyses, are shown in table 1.

Table 1. Composition of steels

\begin{tabular}{|c|c|c|c|c|}
\hline \multirow{2}{*}{ Element } & \multicolumn{3}{|c|}{ SAE X 4130 Steel } & \multirow{2}{*}{$\begin{array}{l}\text { SAE } \\
6130 \\
\text { Steel }\end{array}$} \\
\hline & Lot A & Lot B & Lot C & \\
\hline Carbon & $\begin{array}{c}\text { Percent } \\
0.35\end{array}$ & $\begin{array}{c}\text { Percent } \\
0.29\end{array}$ & $\begin{array}{c}\text { Percent } \\
0.33\end{array}$ & $\begin{array}{c}\text { Percent } \\
0.30\end{array}$ \\
\hline Manganese & .53 & .47 & .55 & .61 \\
\hline Phosphorus & .01 & .02 & .03 & .03 \\
\hline Sulfur......... & .02 & .02 & .01 & .04 \\
\hline Silicon & .21 & .25 & .24 & .25 \\
\hline Chromium...... & .95 & .96 & 1.05 & 1.01 \\
\hline Molybdenum .... & .19 & .24 & 0.20 & (1) \\
\hline Vanadium ..... & (1) & (1) & (1) & 0.22 \\
\hline Nickel...... & (1) & .15 & .17 & (1) \\
\hline
\end{tabular}

1 Not determined.

Lot A of the X4130 steel was supplied by the Naval Aircraft Factory in two heat-treated conditions, normalized to Rockwell hardness number B-89, and quenched and tempered to Rockwell C-39. The 6130 steel was also supplied by the Naval Aircraft Factory but only in the quenched and tempered condition, Rockwell C-33. The other lots of X4130 rod were heat-treated at the National Bureau of Standards; they were quenched in oil from $1,575^{\circ}$ to $1,600^{\circ} \mathrm{F}$ and subsequently tempered to approximately Rockwell C-40.

Typical microstructures of transverse sections of the steels are shown in figure 1. A longitudinal section of the normalized X4130 steel (not illustrated) showed definite indications of banding and segregation, which are not unusual for this type of steel.

\section{Specimens and Test Methods}

\section{Preparation and Testing of Specimens}

Specimens for the fatigue tests were of the usual "R. R. Moore type" [4] with nominal diameters
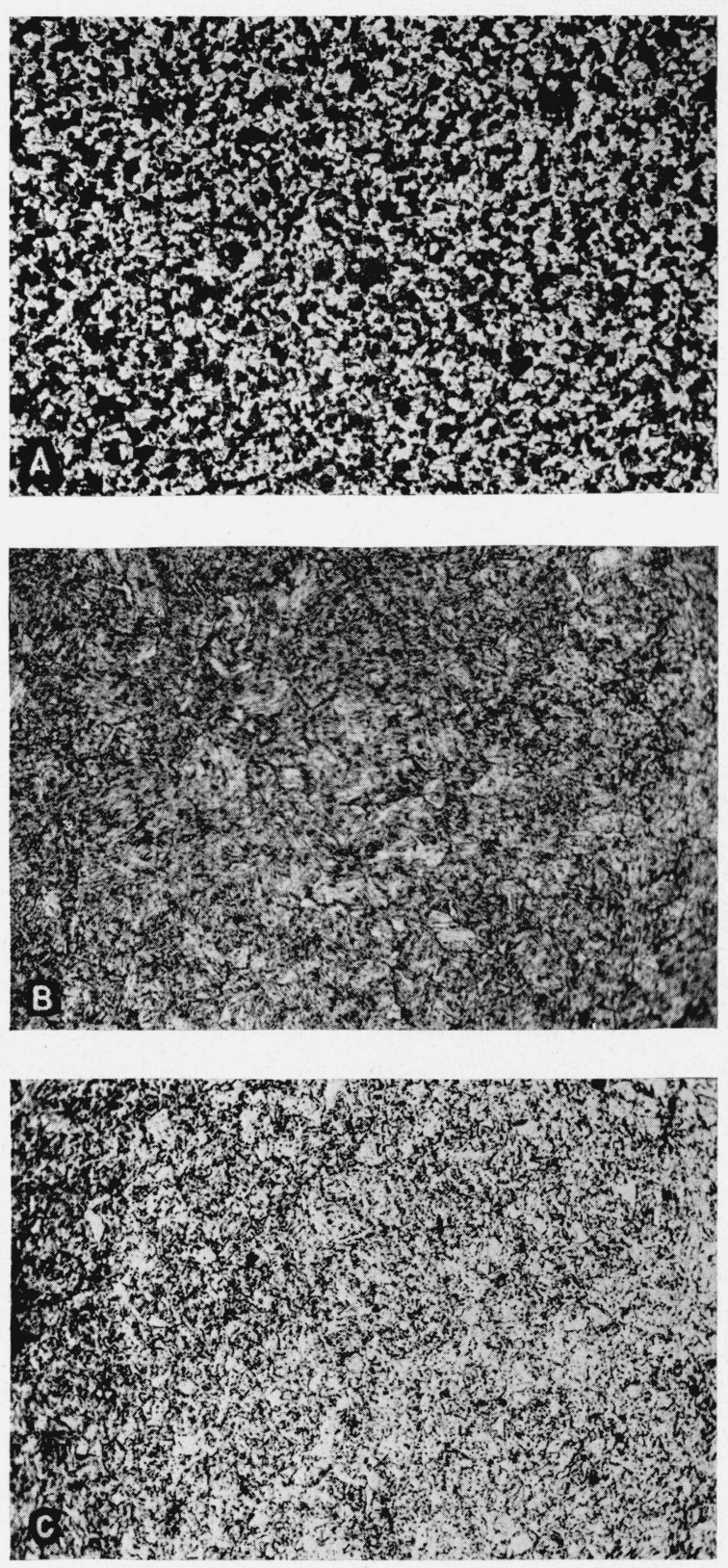

Figure 1. Typical microstructures of transverse sections of steels investigated

A, normalized X4130 steel, x100; B, Quenched and tempered X4130 steel, x500; C, quenched and tempered 6130 steel, x500. All etched 1 percent Nital.

of $0.30 \mathrm{in}$. in most cases; however, 0.25 -in.-diameter specimens were used in some instances. Computation of the stresses in the outer fibers of the specimens, and hence the endurance limits, were based on the diameters of the specimens prior to plating. Diameters of all specimens machined at this Bureau were determined, before 
TABLE 2. Details of preparation of specimens used in the investigation

\begin{tabular}{|c|c|c|c|c|c|c|c|c|}
\hline $\begin{array}{l}\text { SAE } \\
\text { No. }\end{array}$ & $\begin{array}{l}\text { Steel } \\
\text { lot }\end{array}$ & Heat treatment & $\begin{array}{l}\text { Rockwell } \\
\text { hardness }\end{array}$ & $\begin{array}{l}\text { Specimens } \\
\text { prepared } \\
\text { for plating by }{ }^{1}\end{array}$ & $\begin{array}{l}\text { Specimens } \\
\text { chromium } \\
\text { plated by }\end{array}$ & $\begin{array}{l}\text { Temper- } \\
\text { ature of } \\
\text { plating } \\
\text { bath }\end{array}$ & $\begin{array}{l}\text { Plating } \\
\text { current } \\
\text { density }\end{array}$ & $\begin{array}{c}\text { Nominal thickness of } \\
\text { plating }\end{array}$ \\
\hline $\begin{array}{r}\mathrm{X} 4130 \\
\mathrm{X} 4130 \\
\mathrm{X} 4130 \\
\mathrm{X} 4130 \\
6130 \\
6130 \\
\mathrm{X} 4130 \\
\mathrm{X} 4130 \\
\mathrm{X} 4130 \\
\mathrm{X} 4130\end{array}$ & $\begin{array}{c}\text { A } \\
\text { A } \\
\text { A } \\
\text { A } \\
-- \\
\text { B } \\
\text { C } \\
\text { C } \\
\text { C }\end{array}$ & $\begin{array}{l}\text { Oil quenched from } 1,575 \text { to } \\
1,600^{\circ} \mathrm{F} \text {. drawn at } 900 \text { to } \\
925^{\circ} \mathrm{F} \text {. }\end{array}$ & $\begin{array}{l}89-\mathrm{B} \\
89-\mathrm{B} \\
39-\mathrm{C} \\
39-\mathrm{C} \\
33-\mathrm{C} \\
33-\mathrm{C} \\
40-\mathrm{C} \\
40-\mathrm{C} \\
40-\mathrm{C} \\
40-\mathrm{C}\end{array}$ & 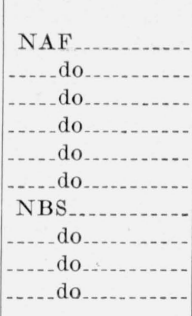 & 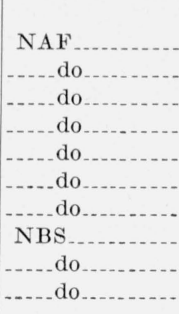 & $\begin{array}{l}{ }^{\circ} \mathrm{C} \\
55 \\
70 \\
55 \\
70 \\
55 \\
70 \\
70 \\
70 \\
55 \\
85\end{array}$ & $\begin{array}{c}a m p / s q . f t . \\
200 \\
1,000 \\
200 \\
1,000 \\
200 \\
1,000 \\
1,000 \\
1,000 \\
350 \\
700\end{array}$ & $\begin{array}{l}\text { in. } \\
0.0001 ; 0.001 ; 0.004 ; 0.009^{2} \\
0.0001 ; 0.001 ; 0.004 ; 0.009^{2} \\
0.0001 ; 0.001 ; 0.004 ; 0.009^{2} \\
0.0001 ; 0.001 ; 0.004 ; 0.009^{2} \\
0.0001 ; 0.001 ; 0.004 ; 0.009^{2} \\
0.0001 ; 0.001 ; 0.004 ; 0.009^{2} \\
0.009 \\
0.009 \\
0.001 \cdot 0.005 ; 0.010 ; 0.017 . \\
0.010 \text {. }\end{array}$ \\
\hline
\end{tabular}

${ }^{1}$ Includes heat treating, machining, and usually polishing.

${ }^{2}$ Two groups of specimens had been plated to a thickness of about 0.008 in. One of these groups was stated to have been plated to a thickness of 0.010 in. with about $0.001 \mathrm{in}$. of plate subsequently removed by grinding.

and after plating, with a dial gage comparator reading to $0.0001 \mathrm{in}$.

Prior to the final polishing, the specimens prepared at this Bureau were ground with a Norton "38" alundum wheel. Subsequently these grinding marks were removed with metallographic polishing papers by one of the following methods: (a) circumferential polishing of specimens in a lathe for fixed periods, determined by experiment to be sufficient to remove grinding marks or marks of coarser papers previously used (papers used were Behr-Manning emery 1, Aloxite 400, BehrManning emery $1 / 0$ and $2 / 0$ ); or (b) longitudinal polishing of specimens using Aloxite 400 paper followed by the Behr-Manning emery $1 / 0$ polishing paper in the form of belts mounted on a rubberbacked wheel. In some instances commercially available coarse and medium emery-impregnated rubber wheels were used in place of the abrasive paper belts.

A few of the mechanically polished specimens were subsequently polished electrolytically as follows: Specimens were made the anodes in a bath containing 50 percent by volume of concentrated $\mathrm{H}_{2} \mathrm{SO}_{4}$ and 50 percent by volume of 75 percent $\mathrm{H}_{3} \mathrm{PO}_{4}$; a current density of $250 \mathrm{amp} / \mathrm{ft}^{2}$ was maintained for 5 minutes; the temperature was $42^{\circ} \mathrm{C}$. This reduced the diameters of the specimens by 0.0004 to 0.0006 in. Details regarding the preparation of the fatigue specimens are given in table 2 .

Fatigue tests were made in R. R. Moore type rotating beam fatigue testing machines operating at 1,800 or 3,600 revolutions per minute with stresses generally applied in increments of 1,000 $\mathrm{lb} / \mathrm{in}^{2}$. Generally, eight to ten specimens were required to obtain the endurance limit in any one case. Specimens that had run $10,000,000$ or more cycles without failure were considered to have been stressed at or below the endurance limit and were removed from the machines.

\section{Electroplating of Specimens}

Specimens were plated at the National Bureau of Standards by personnel of the Electrodeposition Section. The process prior to plating was as follows: Specimens were cleaned by scrubbing with fine pumice powder and rinsed thoroughly with water. The light oxide film that formed during the time required to assemble the specimens in the plating rack was removed by dipping for a few seconds in 20-percent hydrochloric acid solution. The specimens were again rinsed, placed in the chromium plating solution, and made anodic for 1 minute at the same current density used in plating. After the anodic treatment, full plating current was immediately applied.

The plating electrolyte contained $250 \mathrm{~g}$ /liter of $\mathrm{CrO}_{3}$ and $2.5 \mathrm{~g}$ /liter of $\mathrm{H}_{2} \mathrm{SO}_{4}$. Specimens were plated at three different bath temperatures and current densities. A bath temperature of $55^{\circ} \mathrm{C}$ and a current density of $350 \mathrm{amp} / \mathrm{ft}^{2}$ were selected as one condition, because they were within the range $\left(45^{\circ}\right.$ to $60^{\circ} \mathrm{C}$. and 70 to 450 amp $\left./ \mathrm{ft}^{2}\right)$ generally used in industrial chromium plating. A temperature of $70^{\circ} \mathrm{C}$ and a current density of $1,000 \mathrm{amp} / \mathrm{ft}^{2}$ were employed for the second condition in order to check certain results previously obtained in this investigation on 

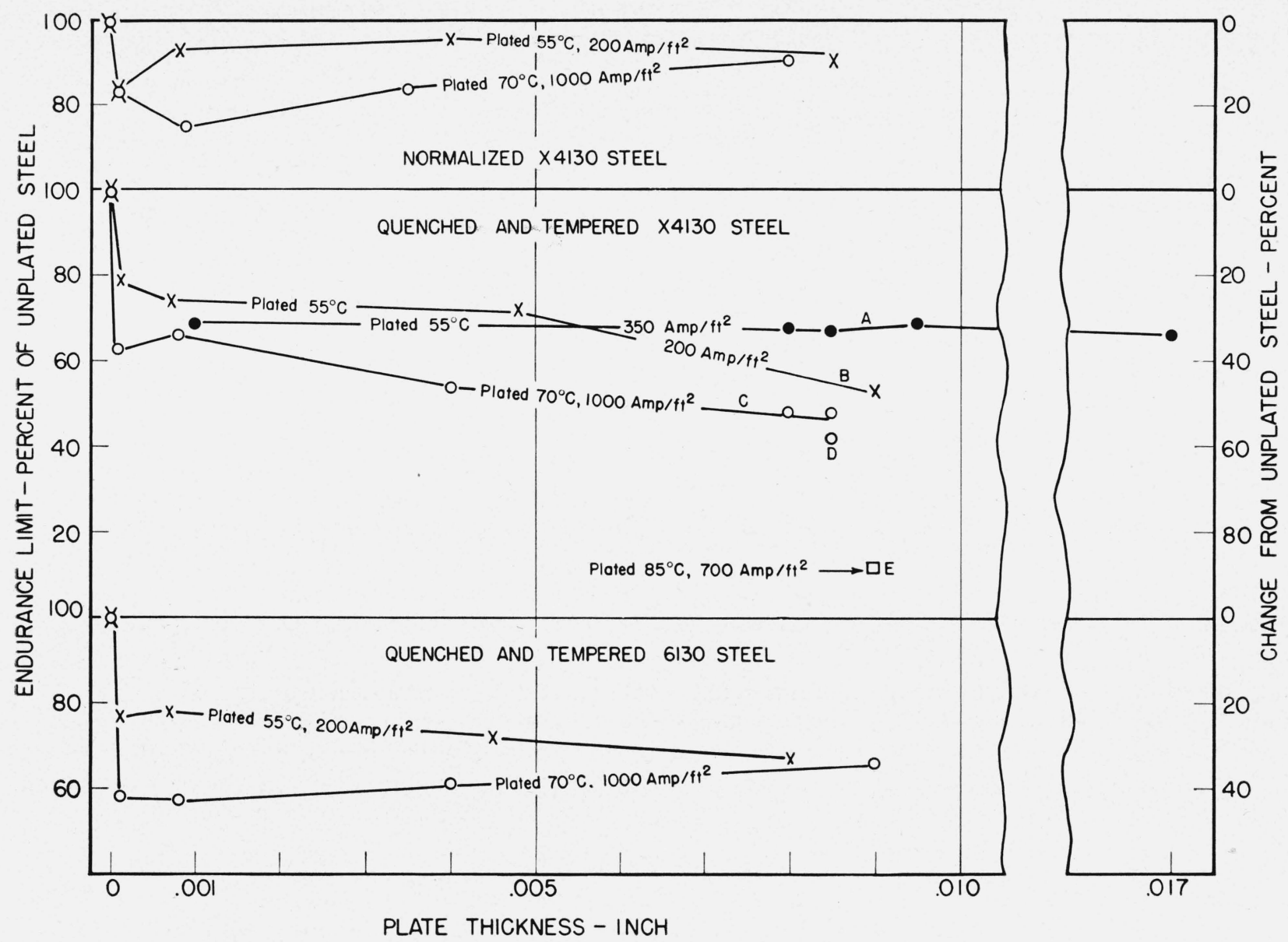

FIGURE 2. Relationship between the endurance limits and plate thicknesses of X4130 and 6130 steels.

Data obtained on specimens plated at NBS are shown by curve A and points D and E. All other data were obtained on specimens plated at the NAF.

specimens similarly plated at the Naval Aircraft Factory. A bath temperature of $85^{\circ} \mathrm{C}$ and a current density of $700 \mathrm{amp} / \mathrm{ft}^{2}$ were selected for the third condition, since chromium deposited in this way is supposed to be subject to less contraction when heated than is chromium plated under the other conditions, and it appeared advisable to determine the extent to which this factor might affect the endurance limit of the steel.-

In order to determine the effect of interrupted plating on the endurance limit, two sets of specimens were plated to the same final thickness; one set was plated continuously and the other by an interrupted operation. Plating was resumed following the interruption only after the employment of the proper commercial technique for plating chromium on chromium; this involved a short reversal of the current and the gradual increasing of the current from a low value to the plating current.
No information was provided by the Naval Aircraft Factory as to the surface preparation, after the final machining and prior to plating, of fatigue specimens prepared at that agency. The composition of the plating bath used by the Naval Aircraft Factory in plating of fatigue specimens was the same as that used at this Bureau and described above; specimens were stated to have been plated in a bath maintained at $55^{\circ} \mathrm{C}$ at a current density of $209 \mathrm{amp} / \mathrm{ft}^{2}$ and at $70^{\circ} \mathrm{C}$ and $1,000 \mathrm{amp} / \mathrm{ft}^{2}$.

\section{Heat Treatment of Chromium-Plated Specimens}

Some specimens were heated in oil at about $100^{\circ} \mathrm{C}$, in boiling ethylene glycol at $193^{\circ} \mathrm{C}$, or in N-butal phthalate at $297^{\circ} \mathrm{C}$. Other specimens were heated to temperatures up to $200^{\circ} \mathrm{C}$ in an electrically heated laboratory oven, with forced air circulation, thermostatically controlled to $\pm 2^{\circ} \mathrm{C}$. Temperatures of $300^{\circ}, 350^{\circ}, 400^{\circ}$, and 
$440^{\circ} \mathrm{C}$, controlled to $\pm 3^{\circ} \mathrm{C}$, were obtained with an electrically heated tempering furnace with forced air circulation.

\section{Results and Discussion}

\section{Effect of Chromium Plating on the Endurance Limits of SAE X4130 and SAE 6130 Steels}

\section{(a) Normalized X4130 Steel}

The results of fatigue tests on the normalized $\mathrm{X} 4130$ steel (heat $\mathrm{A}$ ) are given in table 3 and shown graphically in figure 2 . The decrease in the endurance limit of the normalized steel caused by chromium plating was generally small; the minimum endurance limit of any group of plated specimens was 75 percent of the endurance limit of the unplated steel. This value was obtained on specimens plated to a thickness of 0.001 in. at a current density of 1,000 amp/ $\mathrm{ft}^{2}$. Most sets of specimens had endurance limits ranging from 83 to 95.5 percent of that of the unplated steel. Specimens plated in the bath at $55^{\circ} \mathrm{C}$ and a current density of $200 \mathrm{amp} / \mathrm{ft}^{2}$ had endurance limits equal to or greater than those plated at $70^{\circ} \mathrm{C}$ and 1,000 $\operatorname{amp} / \mathrm{ft}^{2}$.

\section{(b) Quenched and Tempered SAE X4130 Steel}

The results of fatigue tests on quenched and tempered SAE X4130 steel (lots A, B, and C), hardness approximately 40 Rockwell $\mathrm{C}$, bare, and plated to various thicknesses under various plating conditions are given in table 3. Most of the data are also shown graphically in figure 2 . The endurance limits of the quenched and tempered steel specimens were reduced much more by chromium plating than were those of the normalized specimens (hardness, Rockwell 89-B). The maximum endurance limits of specimens plated to a thickness of 0.008 to 0.010 inch at a bath temperature of $55^{\circ} \mathrm{C}$ and tested as plated were 68 to 69 percent of that of the unplated steel. Endurance limits of the specimens in general decreased with increased bath temperatures. Specimens plated at $70^{\circ} \mathrm{C}$ to the same thickness as those plated at $55^{\circ} \mathrm{C}$ and discussed above had endurance limits 40 to 48 percent of that of the unplated steel, and

TABLE 3. Endurance limits of unplated and chromium-plated steels

\begin{tabular}{|c|c|c|c|c|c|c|c|c|c|c|c|c|c|}
\hline \multirow[b]{2}{*}{ Steel } & \multicolumn{13}{|c|}{ Nominal plating thickness- } \\
\hline & 0 inch & \multicolumn{2}{|c|}{0.0001 inch } & \multicolumn{2}{|c|}{0.001 inch } & \multicolumn{2}{|c|}{0.004 inch } & \multicolumn{2}{|c|}{0.009 inch } & \multicolumn{2}{|c|}{$\begin{array}{l}\text { Ground to } \\
0.009 \text { inch }\end{array}$} & \multicolumn{2}{|c|}{0.017 inch } \\
\hline \multicolumn{14}{|c|}{ PLATED AT $70^{\circ} \mathrm{C}$-CURRENT DENSITY $1,000 \mathrm{AMP} / \mathrm{FT}{ }^{2}$} \\
\hline $\begin{array}{l}\text { Normalized X4130. Hardness, Rock- } \\
\text { well 89-B } \\
\text { Q \& T 6130. Hardness, Rockwell 33-C. } \\
\text { Q \& T X4130. Hardness, Rockwell 39-C. }\end{array}$ & $\begin{array}{l}l b / \text { in }^{2} \\
44,000 \\
83,000 \\
93,000\end{array}$ & $\begin{array}{l}l b / \text { in. }^{2} \\
36,500 \\
48,000 \\
59,000\end{array}$ & $\begin{array}{l}\%^{1} \\
83 \\
58 \\
63\end{array}$ & $\begin{array}{l}l b / \text { in }^{2} \\
33,000 \\
47,000 \\
61,000\end{array}$ & $\begin{array}{c}\%^{1} \\
75 \\
57 \\
66\end{array}$ & $\begin{array}{c}\text { lb/in. } .^{2} \\
37,000 \\
51,000 \\
50,000\end{array}$ & $\begin{array}{l}\%^{1} \\
84 \\
61 \\
54\end{array}$ & $\begin{array}{c}\text { lb/in. }{ }^{2} \\
40,000 \\
55,000 \\
45,000\end{array}$ & $\begin{array}{c}\%^{1} \\
91 \\
66 \\
48\end{array}$ & $\begin{array}{l}l b / \text { in }^{2} \\
38,000 \\
55,000 \\
58,000\end{array}$ & $\begin{array}{r}\%^{1} \\
86 \\
66 \\
62\end{array}$ & \begin{tabular}{c|} 
lb/in. \\
2 \\
$\cdots$ \\
$\cdots$
\end{tabular} & $\% 1$ \\
\hline \multicolumn{14}{|c|}{ PLATED AT $55^{\circ} \mathrm{C}-\mathrm{CURRENT}$ DENSITY $200 \mathrm{AMP} / \mathrm{FT}^{2}$} \\
\hline $\begin{array}{l}\text { Normalized X4130. Hardness, Rock- } \\
\text { well 89-B } \\
\text { Q \& T 6130. Hardness, Rockwell 33-C. } \\
\text { Q \& T X4130. Hardness, Rockwell } \\
\text { 39-C to 40-C. }\end{array}$ & $\begin{array}{l}44,000 \\
83,000 \\
93,000\end{array}$ & $\begin{array}{l}37,000 \\
64,000 \\
73,000\end{array}$ & $\begin{array}{l}84 \\
77 \\
79\end{array}$ & $\begin{array}{l}41,000 \\
65,000 \\
69,000\end{array}$ & $\begin{array}{l}93 \\
78 \\
74\end{array}$ & $\begin{array}{l}42,000 \\
60,000 \\
67,000\end{array}$ & $\begin{array}{l}95.5 \\
72 \\
62\end{array}$ & $\begin{array}{r}40,000 \\
56,000 \\
49,000\end{array}$ & $\begin{array}{l}91 \\
67 \\
53\end{array}$ & $\begin{array}{l}45,000 \\
61,000 \\
65,000\end{array}$ & $\begin{array}{r}102 \\
74 \\
70\end{array}$ & -... & $\ldots$ \\
\hline \multicolumn{14}{|c|}{ PLATED AT $55^{\circ} \mathrm{C}$-CURRENT DENSITY 350 AMP/FT 2} \\
\hline $\begin{array}{l}\text { Q \& } \mathrm{T} \text { X4130. Hardness, Rockwell } \\
39-\mathrm{C} \text { to } 40-\mathrm{C} .\end{array}$ & 93,000 & .... & $\ldots$ & 66,000 & 71 & -... & $\ldots$ & 64,000 & 69 & -... &.-- & 61,000 & 66 \\
\hline \multicolumn{14}{|c|}{ PLATED AT $85^{\circ} \mathrm{C}$-CURRENT DENSITY $700 \mathrm{AMP} / \mathrm{FT}^{2}$} \\
\hline $\begin{array}{l}\text { Q \& T X4130. Hardness, Rockwell } \\
39-\mathrm{C} \text { to } 40-\mathrm{C} .\end{array}$ & 93,000 & -... & --- & -..- & -...- & ...- & -...- & 10,000 & 11 & -... &.-- & -... & -... \\
\hline
\end{tabular}

1 Percentage of unplated steel. 
those plated at $85^{\circ} \mathrm{C}$ only 11 percent of that of the unplated steel.

Endurance limits of specimens of the quenched and tempered steel, plated at the Naval Aircraft Factory (table 2), generally decreased with increased plate thickness (fig. 2, curves B and C). There was no significant change in endurance limit with increased plate thickness for specimens plated at $55^{\circ} \mathrm{C}$ at the NBS (fig. 2, curve A). Plating at this Bureau in the bath at $55^{\circ} \mathrm{C}$ was at a current density of $350 \mathrm{amp} / \mathrm{ft}^{2}$ as compared to a current density of $200 \mathrm{amp} / \mathrm{ft}^{2}$ at that temperature at the Naval Aircraft Factory. Specimens plated by the Naval Aircraft Factory to a thickness of approximately 0.009 in. at $70^{\circ} \mathrm{C}$, current density $1,000 \mathrm{amp} / \mathrm{ft}^{2}$, had a 14 -percent higher endurance limit than specimens plated under the same conditions at this Bureau. Curve $C$, fig. 2 represents Naval Aircraft Factory specimens, and point $D$, National Bureau of Standards specimens.

There was no significant difference in the endurance limits of two sets of specimens, both plated to the same final thickness under similar conditions, of which one was plated continuously and the other by an interrupted operation.

\section{(c) Quenched and Tempered SAE 6130 Steel}

The results of fatigue tests on the quenched and tempered SAE 6130 steel (hardness Rockwell 33-C), bare and plated to various thicknesses at current densities of 1,000 and $200 \mathrm{amp} / \mathrm{ft}^{2}$, are given in table 3 and are shown graphically in figure 2 .

Endurance limits of specimens plated at $70^{\circ} \mathrm{C}$ increased as the plating thickness was increased above $0.001 \mathrm{in}$.; on the other hand, the endurance limits of specimens plated at $55^{\circ} \mathrm{C}$ decreased with increased plate thickness above that value. The endurance limits of specimens with 6.009-in. thick plating were approximately the same for both sets of plating conditions and amounted to 66 to 67 percent of that of the unplated steel. Specimens plated to thicknesses of 0.0001 and $0.001 \mathrm{in}$. had endurance limits of 77 to 78 and 57 to 58 percent of that of the unplated steel for bath temperatures of $55^{\circ}$ and $70^{\circ} \mathrm{C}$, respectively.

The data obtained on the ground and unground specimens having approximately the same final plate thickness (0.009 in.), in general, indicated that the ground specimens had endurance limits equal to or greater than those of the "as plated" specimens (table 3 ).

\section{Effect of Heating on the Endurance Limit of Chromium-Plated X4130 Steel}

The results of fatigue tests on specimens of lots $\mathrm{B}$ and $\mathrm{C}$ of the SAE X4130 steel, chromium plated to thicknesses of 0.001 to 0.017 in. and subsequently baked at temperatures ranging from $100^{\circ} \mathrm{C}$ to $440^{\circ} \mathrm{C}$, are given in tables 4,5 , and 6 ; some of the data are shown graphically in figures 3 and 4 . The endurance limits of these specimens reached a minimum value for temperatures between $193^{\circ}$

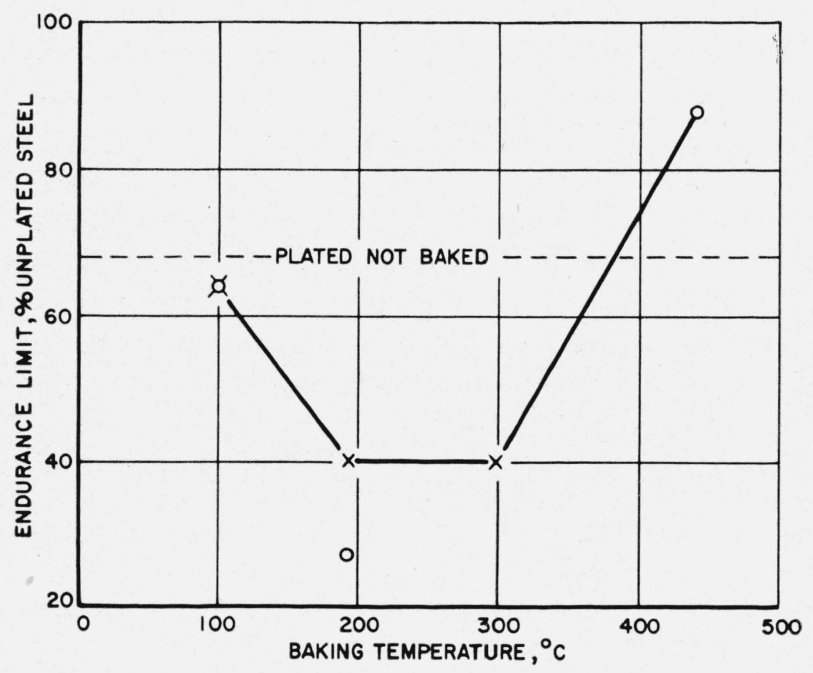

FIgURE 3. Influence of baking temperatures on the endurance limits of quenched and tempered $X_{4} 130$ steel specimens chromium plated at $55^{\circ} \mathrm{C}$ and a current density of $350 \mathrm{amp} / \mathrm{ft}^{2}$ to a thickness approximately $0.008 \mathrm{in}$.

$\mathrm{O}$, Baked in air; $\mathrm{X}$, baked in an organic liquid.

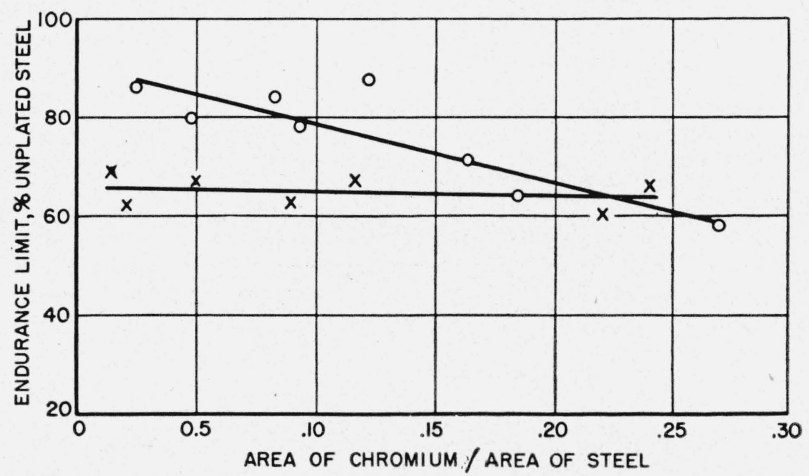

FIgURE 4. Relationship between endurance limit and ratio of cross-sectional chromium-plated area to steel area for quenched and tempered SAE X4130 steel specimens 0.250 and $0.300 \mathrm{in}$. in diameter.

$\mathrm{X}$, As plated; $\bigcirc$, plated and baked 1 hour at $440^{\circ} \mathrm{C}$. 
TABLE 4. Endurance properties of SAE $X_{4} 130$ steel specimens (hardness, approximately $40 \mathrm{C}$ scale) chromium plated and subsequently heated

\begin{tabular}{|c|c|c|c|c|c|}
\hline & \multicolumn{3}{|c|}{ Heat treatment } & \multicolumn{2}{c}{ Endurance limit } \\
\cline { 2 - 3 } $\begin{array}{c}\text { Nominal } \\
\text { thick- } \\
\text { ness of } \\
\text { plating }\end{array}$ & $\begin{array}{c}\text { Temper- } \\
\text { ature }\end{array}$ & Medium & Time & lb/in.2 & $\begin{array}{c}\text { Percent- } \\
\text { age of } \\
\text { unplated } \\
\text { steel }\end{array}$ \\
\hline
\end{tabular}

LOT C STEEL, PLATING BATH TEMPERATURE $55^{\circ} \mathrm{C}$, CURRENT DENSITY 350 AMP/FT 2

\begin{tabular}{|c|c|c|c|c|c|}
\hline in. & ${ }^{\circ} \mathrm{C}$ & & $h r$ & & \\
\hline 0.0085 & ....... & None... & ...... & 64,000 & 67 \\
\hline .009 & 100 & Oil_..... & 1 & 56,000 & 64 \\
\hline .010 & 100 & ...... do & 12 & $<48,000$ & $<55$ \\
\hline .0095 & 193 & Ethylene glycol_ & 1 & 35,000 & 40 \\
\hline .0105 & 193 & do & 6 & 33,000 & 37.5 \\
\hline .0100 & 193 & do & 100 & 33,000 & 37.5 \\
\hline .0105 & 193 & Air & 1 & 24,000 & 27 \\
\hline .0085 & 200 & ..... do do...... & 6 & 32,000 & 34 \\
\hline .0087 & 296 & Butal phthalate & 1 & 35,000 & 40 \\
\hline .009 & 440 & Air & 1 & 83,000 & 87.5 \\
\hline
\end{tabular}

LOT B STEEL, PLATING BATH TEMPERATURE $70^{\circ} \mathrm{C}$, CURRENT DENSITY 1,000 AMP/FT 2

\begin{tabular}{|c|c|c|c|c|c|}
\hline .008 & & None & & 45,000 & 51 \\
\hline .008 & 95.5 & Oil... & 24 & 39,000 & 44 \\
\hline .008 & 95.5 & Air... & 24 & 35,000 & 40 \\
\hline .008 & 200 & .... do .. & 6 & 32,000 & 36 \\
\hline .008 & 300 & .... do . & 4 & 46,000 & 52 \\
\hline .008 & 350 & $\ldots$ do $\ldots$ & 1 & 51,000 & 58 \\
\hline .008 & 400 & .... do & 1 & 55,000 & 63 \\
\hline .008 & 440 & ..... do .... & 1 & 59,000 & 67 \\
\hline \multicolumn{6}{|c|}{$\begin{array}{l}\text { LOT C STEEL, PLATING BATH TEMPERATURE } 70^{\circ} \mathrm{C} \text {, } \\
\text { CURRENT DENSITY } 1,000 \text { AMP/FT } 2\end{array}$} \\
\hline .009 & - & None. & & 40,000 & 42 \\
\hline .008 & 200 & Air & 6 & 25,000 & 26 \\
\hline .008 & 300 & $\ldots$ do & 4 & 28,000 & 28.5 \\
\hline .008 & 440 & ..... do do... & 1 & 47,000 & 49.5 \\
\hline \multicolumn{6}{|c|}{$\begin{array}{l}\text { LOT C STEEL, PLATING BATH TEMPERATURE } 85^{\circ} \mathrm{C} \text {, } \\
\text { CURRENT DENSITY } 700 \text { AMP/FT } 2\end{array}$} \\
\hline .010 & -...... & None.. & $-\cdots$ & 10,000 & \\
\hline .010 & 193 & Ethylene glycol & 6 & 13,000 & 14.5 \\
\hline .010 & 440 & Air & 1 & 42,000 & 46.5 \\
\hline
\end{tabular}

and $300^{\circ} \mathrm{C}$; at higher baking temperatures the endurance limits increased, and at temperatures of $400^{\circ}$ and $440^{\circ} \mathrm{C}$ exceeded those of the unbaked plated specimens. The endurance limit of one set of specimens heated in air for 1 hour at $193^{\circ} \mathrm{C}$ was 27 percent of that of the unplated steel (table 4). The endurance limit of specimens heated in ethylene glycol at $193^{\circ} \mathrm{C}$ was somewhat higher than that of specimens heated in air and was independent of the time specimens were held at the baking temperature. Specimens plated to a thick- ness of $0.002 \mathrm{in}$. and heated for 1 hour at $440^{\circ} \mathrm{C}$ had an endurance limit as high as $87 \frac{1}{2}$ percent of that of the unplated steel compared to 68 to 69 percent for unbaked plated specimens. However, the endurance limits of the plated specimens heated 1 hour at $440^{\circ} \mathrm{C}$ decreased as the ratio of the cross-sectional area of chromium plating to steel

TABLE 5. Effect of specimen diameter and plating thickness on the endurance limit of quenched and tempered SAE $X_{4130}$ steei, hardness Rockwell, 40-C, lot C, chromium plated at a current density of 350 amp/ft ${ }^{2}$, bath temperature $55^{\circ} \mathrm{C}$

\begin{tabular}{|c|c|c|c|c|c|c|}
\hline \multirow{2}{*}{$\begin{array}{l}\text { Specimen } \\
\text { diameter }\end{array}$} & \multirow{2}{*}{$\begin{array}{l}\text { Nominal } \\
\text { plate } \\
\text { Thickness }\end{array}$} & \multirow{2}{*}{$\begin{array}{c}\text { Ratio of } \\
\text { cross- } \\
\text { sectional } \\
\text { chromium } \\
\text { plate to } \\
\text { steel area }\end{array}$} & \multicolumn{2}{|c|}{$\begin{array}{l}\text { Baking treat- } \\
\text { ment }\end{array}$} & \multirow{2}{*}{$\begin{array}{c}\text { Endur- } \\
\text { ance } \\
\text { limit }\end{array}$} & \multirow{2}{*}{$\begin{array}{l}\text { Percent- } \\
\text { age of } \\
\text { endurance } \\
\text { limit of } \\
\text { unplated } \\
\text { steel }\end{array}$} \\
\hline & & & Time & $\begin{array}{l}\text { Temper- } \\
\text { ature }\end{array}$ & & \\
\hline $\begin{array}{c}\text { in. } \\
0.25 \text { to } 0.30\end{array}$ & in. & 0 & $h r$ & ${ }^{\circ} \mathrm{C}$. & $\begin{array}{l}l b / \text { in }^{2} \\
95,000\end{array}$ & $\begin{array}{l}\text { Percent } \\
100\end{array}$ \\
\hline .30 & 0.017 & 0.24 & $\ldots$ & - n. & 63,000 & 66 \\
\hline .30 & .0085 & .116 & $\ldots$ & - . - & 64,000 & 67 \\
\hline .30 & .001 & .014 & .... & - n... & 66,000 & 69 \\
\hline .25 & .0105 & .22 & $\ldots$ & - n. & 57,000 & 60 \\
\hline .25 & .005 & .090 & .... & -..... & 59,000 & 62 \\
\hline .25 & .001 & .021 & $\ldots$ & - . . & 59,000 & 62 \\
\hline .30 & .0085 & .116 & 2 & 200 & 31,000 & 33 \\
\hline .30 & .0085 & .116 & 6 & 200 & 31,000 & 33 \\
\hline .30 & .018 & .265 & 1 & 440 & $<55,000$ & $<58$ \\
\hline .25 & .002 & .122 & 1 & 440 & 83,000 & 87.5 \\
\hline .25 & .011 & .184 & 1 & 440 & 61,000 & 64 \\
\hline .25 & .010 & .164 & 1 & 440 & 67,000 & 71 \\
\hline .25 & .009 & .157 & 2 & 440 & 80,000 & 84 \\
\hline .25 & .012 & .201 & 4 & 440 & 70,000 & 74 \\
\hline .25 & .005 & .082 & 1 & 440 & 80,000 & 84 \\
\hline .25 & .0015 & .024 & 1 & 440 & 82,000 & 86 \\
\hline
\end{tabular}

TABLE 6. Effect of type of surface preparation of the basis steel prior to plating, on the endurance properties of $S A E$ $X_{4} 130$ steel (lot C) chromium plated to a thickness of 0.008 to $0.009 \mathrm{in}$. at a current density of 1,000 a mp/ft $\mathrm{ft}^{2}$

Bath temperature $70^{\circ} \mathrm{C}$

\begin{tabular}{|c|c|c|c|c|}
\hline \multirow{2}{*}{$\begin{array}{l}\text { Type of surface } \\
\text { treatment } 1\end{array}$} & \multicolumn{2}{|c|}{ Heat treatment } & \multirow{2}{*}{$\begin{array}{c}\text { Endurance } \\
\text { limit }\end{array}$} & \multirow{2}{*}{$\begin{array}{l}\text { Percentage of } \\
\text { endurance } \\
\text { limit of un- } \\
\text { plated me- } \\
\text { chanically } \\
\text { polished steel }\end{array}$} \\
\hline & Time & $\begin{array}{l}\text { Temper- } \\
\text { ature }\end{array}$ & & \\
\hline & $h r$ & ${ }^{\circ} \mathrm{C}$ & $l b /$ in $^{2}$ & \\
\hline Mechanical ${ }^{2}$ & - n. & - n & 95,000 & 100 \\
\hline Electrochemical ${ }^{2}$ - & - n & - n.... & 87,000 & 92 \\
\hline Mechanical_....... & - n... & -.... & 40,000 & 42 \\
\hline Electrochemical_.. & - n & - n. & 24,000 & 25 \\
\hline Mechanical_....... & 6 & 200 & 25,000 & 26.5 \\
\hline Electrochemical_.. & 6 & 200 & 24,000 & 25 \\
\hline Mechanical ....... & 1 & 440 & 47,000 & 49.5 \\
\hline Electrochemical_.. & 1 & 440 & 45,000 & 47.5 \\
\hline
\end{tabular}

${ }^{1}$ All specimens were mechanically polished in a longitudinal direction with "400A" Aloxite paper. Subsequerily, specimens labeled "Electrochemical" were made anodes in $\mathrm{H}_{2} \mathrm{SO}_{4}+\mathrm{H}_{3} \mathrm{PO}_{4}$ solution and were reduced about 0.0005 in. in diameter by electrochemical means.

2 Not plated. 
increased, reaching values less than for the unbaked steel for very thick plating.

The endurance limit of specimens polished electrolytically prior to plating and tested without subsequent heating was lower than that of mechanically polished specimens (table 6 ). However, the endurance limits of the plated and heated specimens were independent of the original surface preparation prior to plating.

\section{Discussion of Causes of Effects of Chromium Plating on Endurance Limits of Steels}

Three possible explanations for the fact that the endurance limits of the steels were reduced by the chromium plate have been proposed: The embrittlement due to hydrogen; cracks in the chromium plate at which stress concentrations occur; and the presence of residual stresses in the chromium or steel or both as the result of the plating. It is of course recognized that these factors may be interrelated and possibly be manifestations of one another.

It is well known that the plating efficiency for depositing chromium is low, approximately 15 to 20 percent of the current being used to deposit chromium. Large quantities of hydrogen are produced at the cathode, and the chromium plate has been shown to contain as much as 128 volumes of hydrogen per volume of chromium $[5,6]$. Theories explaining the manner in which the cathodic hydrogen is held in the chromium [7] have been proposed but are not pertinent to the discussion at this point. Zapffe [8] has explained brittleness observed in bend tests on wire plated with chromium as due to hydrogen. Brenner, Burkhead, and Jennings [9] showed that approximately 95 percent of the hydrogen is removed by heating chromium at $450^{\circ} \mathrm{C}$. These facts suggest that the improvement in endurance limit of specimens heated at $440^{\circ} \mathrm{C}$ is due to the expulsion of hydrogen. However, specimens heated at $200^{\circ} \mathrm{C}$ had in some cases only 50 percent of the endurance limit of unheated specimens, whereas data given by Brenner and coworkers showed that approximately half of the hydrogen was removed from the chromium by heating at $200^{\circ} \mathrm{C}$. It is difficult, therefore, to see how the results of the fatigue tests reported here can be attributed directly to hydrogen embrittlement.

At a magnification of 250 diameters, the sur- faces of the electroplated chromium samples studied had a pebble-grained appearance. The specimens plated at $55^{\circ}$ and $70^{\circ} \mathrm{C}$ also exhibited surface cracks having the appearance of grain boundaries (figs. 5 and 6 ). The cracks were less numerous in the specimens plated at $70^{\circ} \mathrm{C}$ than for those plated at the lower temperature. No cracks were found on specimens plated at $85^{\circ} \mathrm{C}$. Metallographic examinations of longitudinal sections of the chromium-plated specimens at distances of $0.01 \mathrm{in}$. or more from the fatigue fracture failed to reveal cracks penetrating through the chromium, or to reveal cracks extending any appreciable distance into the chromium from the outer surface. There were, however, numerous inclusions and voids in the chromium.

Mehr, Oberg, and Teres [10] reported that, in general, the number of cracks in a given area increased as the chromium plate was heated. Other observers [3] had noted that heating of the chromium plate at a temperature as low as $100^{\circ} \mathrm{C}$ tended to widen the cracks. The author found this crack-widening tendency to be more pronounced as the temperature of heating was increased (fig. 7).

Bennett [11] has shown that notches reduce the endurance limit of normalized X4130 steel approximately 20 percent and that fine cracks reduce the endurance limit by more than 50 percent. The presence of cracks in the chromium plated at $55^{\circ}$ and $70^{\circ} \mathrm{C}$ might explain the reduction in the endurance limits of steel specimens plated at these temperatures. However, no cracks were found in chromium plated at $85^{\circ} \mathrm{C}$, and specimens plated at this temperature had the lowest endurance limit of any specimens tested. Furthermore, preliminary results of an investigation, now in progress, indicate that fatigue damage in chromium-plated steel specimens starts below the surface of the chromium and does not appear to be associated with the surface cracks developed during the plating of the chromium. It must be concluded, therefore, that cracks in the chromium do not have the same effect on the endurance limit of specimens as cracks in the basis steel.

It is well-established that residual stresses in a metal markedly influence its endurance limit. The increased endurance limits, obtained by the shot peening [12] of steel parts, are believed to be the result of residual compressive stresses in the surface of the metal. Conversely, residual ten- 


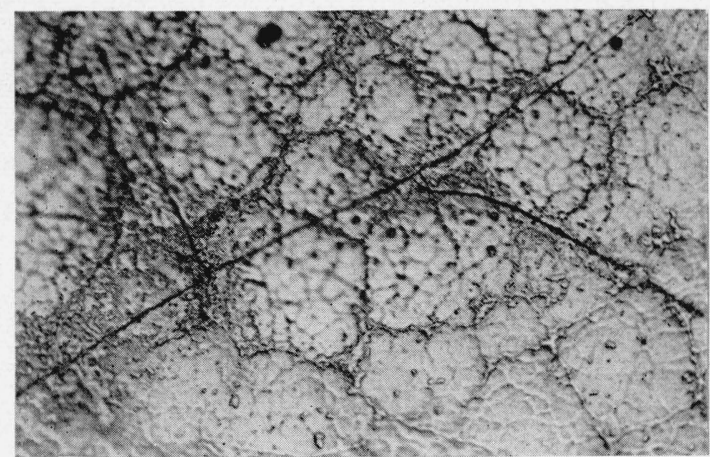

FIGURE 5. Surface of chromium plated on steel at $70^{\circ} \mathrm{C}$ (current density 1,000 amp/ft ${ }^{2}$ ).

Areas bounded by sharply defined cracks are larger than those in chromium plated at $55^{\circ} \mathrm{C}$ (see fig. 6 ). Unetched, $\mathrm{x} 500$.

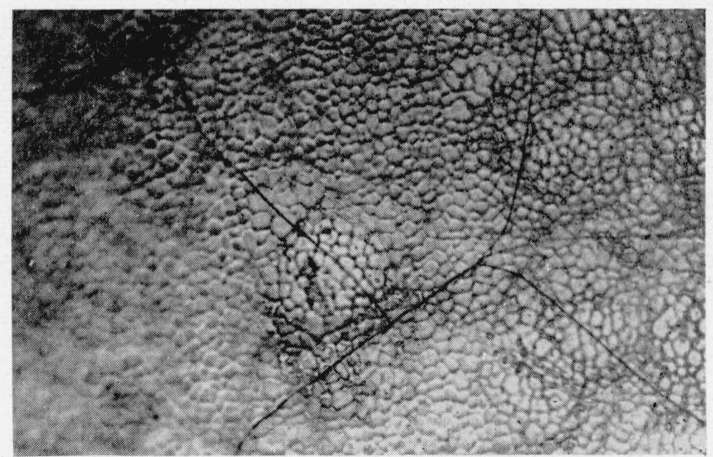

FIgURE 6. Surface of chromium plated on steel at $55^{\circ} \mathrm{C}$ (current density $200 \mathrm{amp} / \mathrm{ft}^{2}$ ).

Unetched, $\mathrm{x} 500$.
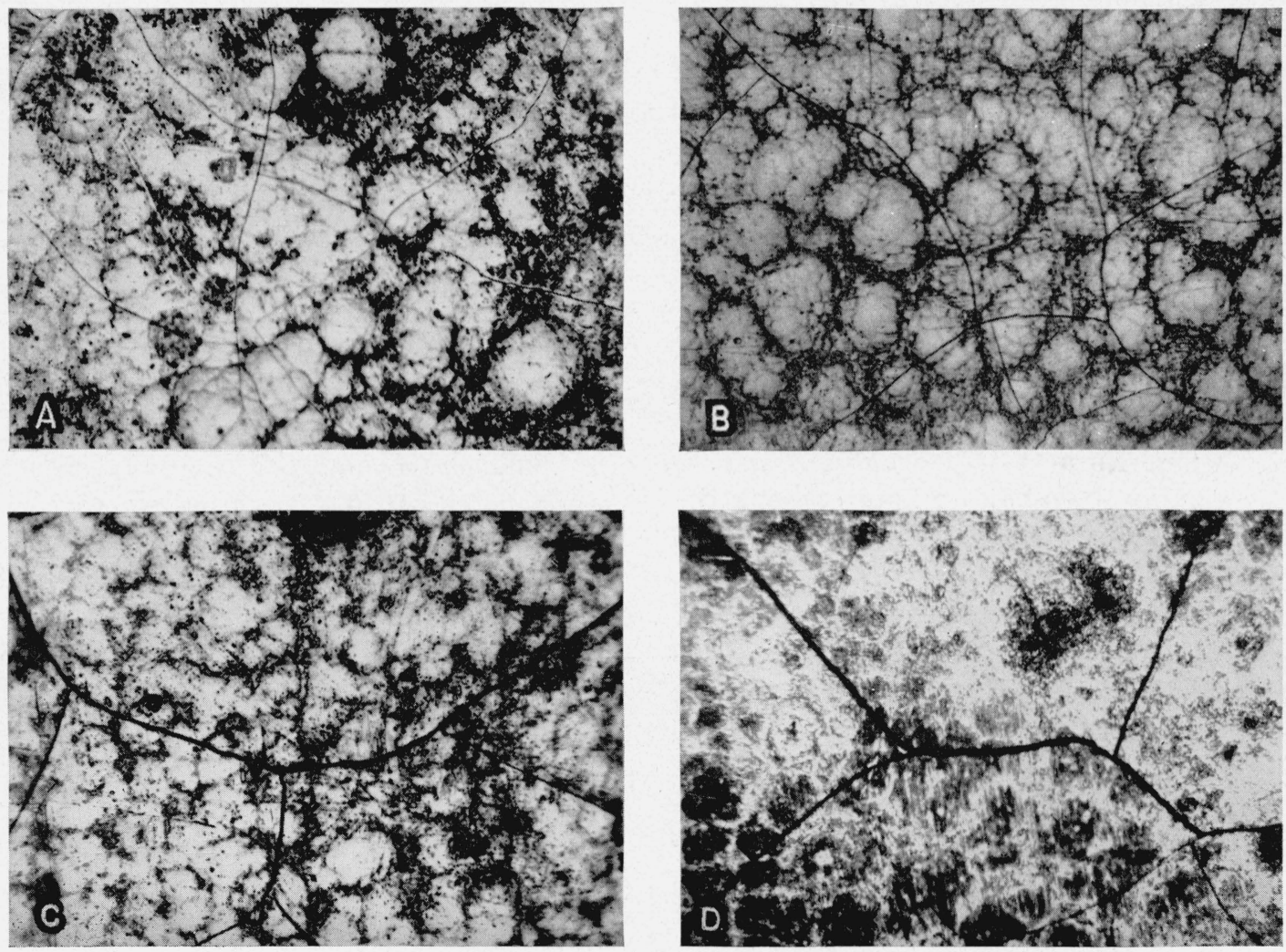

Figure 7. Cracks in chromium plated at $55^{\circ} \mathrm{C}\left(350 \mathrm{amp} / \mathrm{ft}^{2}\right)$; unetched, $x 250$. A, As plated; B, heated $1 \mathrm{hr}$ at $193^{\circ} \mathrm{C}$; C, heated $1 \mathrm{hr}$ at $296^{\circ} \mathrm{C}$; D. heated $1 \mathrm{hr}$ at $440^{\circ} \mathrm{C}$. 


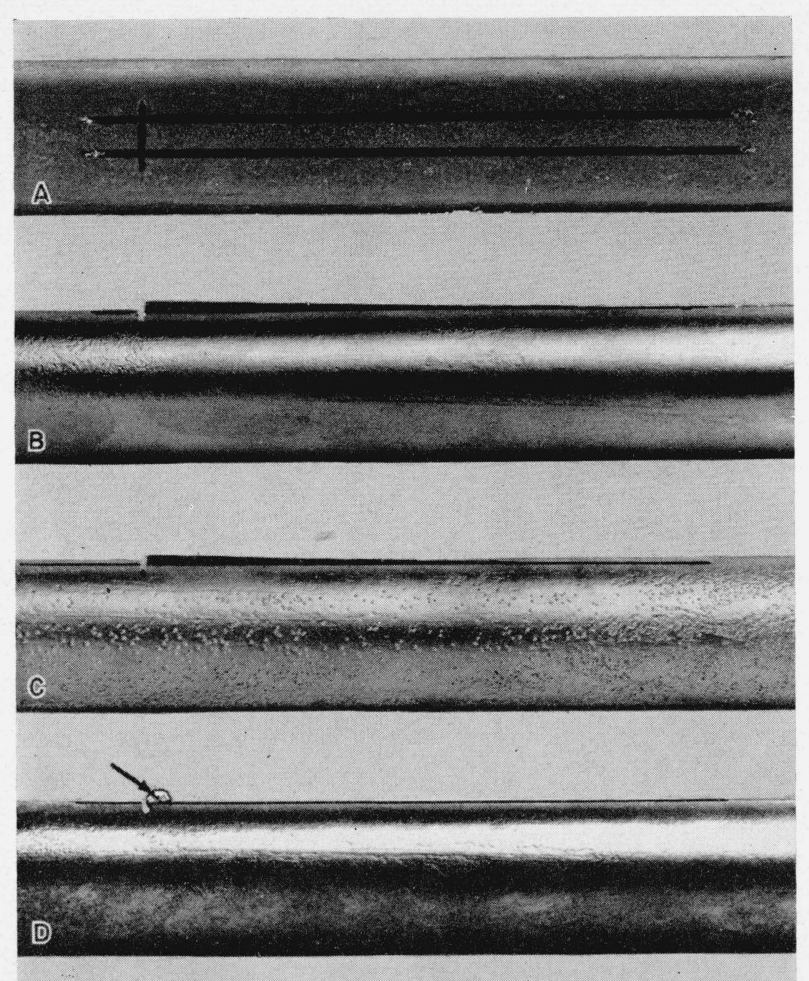

Figure 8. Chromium-plated steel tubes.

A, Top view of tube showing "tongue;" B, C, and D, side views of tubes showing deflections of "tongue." $\mathrm{B}$, tube plated, heated at $200^{\circ} \mathrm{C}$ and "tongue" subsequently cut; C, tube plated, "tongue" cut and tube subsequently heated at $200^{\circ} \mathrm{C} ; \mathrm{D}$, tube plated, heated at $440^{\circ} \mathrm{C}$ and "tongue" cut. A 3/16-in. ball bearing (indicated by arrow) is resting on the depressed "tongue" surface.

sile stresses in the surface layers of the specimens are considered to lower the endurance limit of the material. Hume-Rothery [13] reported tensile stresses as high as $50,000 \mathrm{lb} / \mathrm{in}^{2}{ }^{2}$ in electrolytically deposited chromium. Brenner, Burkhead, and Jennings [9] reported that the residual tensile stresses in chromium plated to a thickness of $8 \times 10-^{4}$ in. increased from approximately 15,000 $\mathrm{lb} /$ in. $^{2}$ for a bath temperature of $50^{\circ} \mathrm{C}$ to over $60,000 \mathrm{lb} / \mathrm{in}^{2}$ for chromium plated from a bath at $85^{\circ} \mathrm{C}$. The endurance limit of specimens plated at $55^{\circ} \mathrm{C}$ was higher than that of specimens plated at $70^{\circ} \mathrm{C}$ and very much higher than that of specimens plated at $85^{\circ} \mathrm{C}$. This is to be expected if the internal stress in the chromium plate increased with the temperature of the plating bath in accordance with Brenner's findings.

The formation of cracks in chromium plating is usually attributed to the rupture of the deposit as the result of high residual tensile stresses [9]. The presence of cracks in the chromium, therefore, indicated at least partial relief of residual stresses. Specimens having the largest number of cracks per unit area, discussed above, would be expected to have the lowest residual stresses, and the residual stresses would be greater as the cracks per unit area decreased (and as the plating temperature increased).

Hidnert [14] showed that an electrodeposited chromium specimen, on the first heating to $500^{\circ} \mathrm{C}$, decreased in length and that during the cooling to room temperature it continued to decrease in length. The net decrease in length amounted to 1.1 percent. Hidnert's results showed an inflection in the heating curve at about $300^{\circ} \mathrm{C}$. Preliminary results of a current investigation by the author indicate that there is an inflection in the temperature-electrical resistivity curve at about this same temperature. Hidnert did not give any data for specimens heated to $200^{\circ} \mathrm{C}$ and cooled to room temperature. In the present investigation, the densities of tubes of chromium were determined for each of the following conditions: "as deposited," after heating at $193^{\circ} \mathrm{C}$ (in boiling ethylene glycol) and after a second heating in helium at $440^{\circ} \mathrm{C}$. The densities were $6.95 \mathrm{~g} / \mathrm{cm}^{3}$ as plated, $7.01 \mathrm{~g} / \mathrm{cm}^{3}$ after heating at $193^{\circ} \mathrm{C}$, and $7.09 \mathrm{~g} / \mathrm{cm}^{3}$ after heating at $440^{\circ} \mathrm{C}$. Brenner [9] indicated that changes in the volume of chromium on heating were isotropic. Hence, heating at $200^{\circ} \mathrm{C}$ would tend to reduce the volume of the plated chromium. If the chromium was restrained from contracting, as for example by being plated on steel, residual tensile stresses would be set up in the chromium that might be expected to lower the endurance limit. That such stresses do exist in chromium plated on steel is shown in figure 8, B and C. Thin-walled steel tubes were annealed, pickled to remove scale, and chromium plated. Tube B, figure 8 , was heated at $200^{\circ} \mathrm{C}$ for 6 hours, and a "tongue" was subsequently cut in the tube. The deflection shown indicated that there had been residual tensile stresses in the chromium. The tongue was cut in tube $\mathrm{C}$ after plating and was deflected only a small amount. Heating at $200^{\circ} \mathrm{C}$, however, caused the chromium to contract in volume and produced the deflection shown.

Heating of chromium at a temperature of $440^{\circ} \mathrm{C}$ produced, as indicated by the density data, more than twice the contraction obtained by heating at $193^{\circ} \mathrm{C}$. It is suggested that if a chromium- 
plated steel specimen is heated to $440^{\circ} \mathrm{C}$, the concurrent expansion of the steel and contraction of the chromium stresses the chromium above its ultimate tensile strength at that temperature, consequently relieving the internal stresses at least in part. This is illustrated on figure 8, tube $\mathrm{D}$, which was heated to $440^{\circ} \mathrm{C}$ for 1 hour, after plating, but prior to cutting of the tongue. In the figure, a $3 / 16$-in. ball is resting on the free end of the tongue, which is depressed below the surface of the tube. The tongue deflected so that the chromium was on its convex surface. This indicated that the chromium had been permanently elongated during the heat treatment due to expansion of the steel; there had been either plastic flow or fractures in the chromium or both.

On the basis of the foregoing discussion, it is postulated that the residual tensile stresses in electrodeposited chromium are a major factor in adversely affecting the endurance limits of steel upon which the chromium is plated. Heating at temperatures of $100^{\circ}$ to $300^{\circ} \mathrm{C}$ tends to contract the chromium; the underlying steel resists this contraction, thus producing increased tensile stresses in the chromium and further reducing the endurance limit. Contraction of the chromium during heating at $400^{\circ}$ and $440^{\circ} \mathrm{C}$, coupled with the expansion of the steel at these temperatures, stressed the chromium beyond its ultimate tensile strength, produced permanent deformation, and hence relieved the stresses in the chromium to some extent with resulting increases in endurance limits of the plated specimens so treated.

\section{Summary}

1. Chromium plating of SAE X4130 and 6130 steels reduced the endurance limits of these materials, as determined in the rotating-beam type of test.

2. The endurance limits of these steels plated under a given set of conditions generally decreased with increased hardness of the steel. For a steel of a given hardness (Rockwell 40-C), the reductions in endurance limit increased with increased plating bath temperatures.

3. The endurance limits of specimens plated, and subsequently surface ground, were equal to or greater than those of unground specimens having the same final plating thickness. Interruption of the plating process did not affect the endurance limit of the plated specimens, provided that proper precautions for plating chromium on chromium were taken before the plating was resumed.

4. The endurance limits of specimens heated after plating and tested at room temperature reached a minimum value for a baking temperature between $190^{\circ}$ and $300^{\circ} \mathrm{C}$. Endurance limits of specimens heated for 1 hour at $440^{\circ} \mathrm{C}$ were significantly higher than those of the "as plated" steel.

5. Reduction of the endurance limits of steel by chromium plating is believed to be due, in part at least, to residual tensile stresses in the chromium. Heating of chromium increased its density and hence decreased its volume. It is postulated that heating at low temperatures increased the residual tensile stresses in the chromium; at sufficiently high temperatures, the concurrent contraction of the chromium and expansion of the steel stressed the chromium above its ultimate tensile strength, thus relieving some of the residual tensile stresses in the chromium and increasing the endurance limit of the plated specimens.

The author gratefully acknowledges the valued advice, aid, and assistance of the following in various phases of this investigation: Naval Aircraft Factory, Philadelphia; N. E. Promisel, Chief Metallurgist, Bureau of Aeronautics, Navy Department, Washington; William Blum and Vernon Lamb of the Bureau's Electrodeposition Section, Harold Hessing, Houston Babb, Thomas P. Royston, Jr., Irene C. Minor, and Lura F. Roehl of the Metallurgy Division of the Bureau. Harold E. Francis, Guy R. McConnell, Richard C. Rohan, and Molly Thompson, formerly of the Metallurgy Division, also assisted in the investigation.

\section{References}

[1] W. H. Swanger and R. D. France, National Bureau of Standards. Unpublished.

[2] H. Wiegand and R. Scheinost, Endurance strength of hard chromium plated parts, Z. Ver. deut. Ing. 83, 655 (1939).

[3] Chromium plating, Bibliography and Correlated Abstract, by M. Kolodney, for War Metallurgy Committee, Information Release No. 4, p. 49 (July 1943).

[4] Metals Handbook (Am. Soc. Metals) p. 120, 1948 ed. 
[5] S. P. Makariewe and N. D. Birükoff, The influence of dissolved hydrogen on the hardness of electrolytic chromium, Z. Elektrochem. 41, 623 (1935).

[6] E. V. Potter and H. C. Lukens, Hydrogen content of electrolytic chromium and its removal, Metals Tech. 15 (January 1948) T. P. 2312.

[7] C. A. Snavely, A theory for the mechanism of chromium plating; a theory for the physical characteristic of chromium plate; Preprint 92-35, Electrochem. Soc. (1947).

[8] C. A. Zapffe and M. E. Haslem, Measurement of embrittlement during chromium and cadmium electroplating and the nature of recovery of plated articles, Trans. Am. Soc. Metals 39, 241 (1947).

[9] A. Brenner, P. Burkhead, and C. Jennings, Physical properties of electrodeposited chromium, J. Research NBS 40, 31 (1948) RP1854.
[10] L. Mehr, T. T. Oberg, and J. Teres, Fatigue limit of chromium plated steel, Monthly Rev. Am. Electroplaters Soc. 34, 1345 (1947).

[11] J. A. Bennett, A study of the damaging effect of fatigue stressing on SAE X4130 steel, J. Research NBS 37, 123 (1946) RP1733.

[12] J. O. Almen, Shot blasting to increase fatigue resistance, SAE Trans. 51, 248 (1943).

[13] W. Hume-Rothery and M. R. J. Wyllie, The structure of electrodeposited chromium, Proc. Roy. Soc. (London) [A] 181, 331 (1943).

[14] P. Hidnert, Thermal expansion of electrolytic chromium, J. Research NBS $\mathbf{2 6 ,} 81$ (1941) RP1361.

Washington, March 30, 1949. 